\title{
Distribution of coastal high water level during extreme events around the UK and Irish coasts
}

\author{
Julia Rulent $^{1,2}$, Lucy M. Bricheno ${ }^{2}$, J. A. Mattias Green ${ }^{1}$, Ivan D. Haigh ${ }^{3}$, and Huw Lewis ${ }^{4}$ \\ ${ }^{1}$ School of Ocean Sciences, College of Environmental Sciences and Engineering, Bangor University, \\ Menai Bridge, United Kingdom \\ ${ }^{2}$ National Oceanography Centre, Liverpool, United Kingdom \\ ${ }^{3}$ School of Ocean and Earth Science, National Oceanography Centre, University of Southampton, \\ Southampton, United Kingdom \\ ${ }^{4}$ Met Office, Exeter, United Kingdom
}

Correspondence: Julia Rulent (jrule@noc.ac.uk)

Received: 20 April 2021 - Discussion started: 26 May 2021

Revised: 9 August 2021 - Accepted: 4 October 2021 - Published: 8 November 2021

\begin{abstract}
The interaction between waves, surges, and astronomical tides can lead to high coastal total water level (TWL), which can in turn trigger coastal flooding. Here, a high-resolution $(1.5 \mathrm{~km})$ simulation from a UK-focused regional coupled environmental prediction system is used to investigate the extreme events of winter 2013/4 around the UK and Irish coasts. The aim is to analyse the spatial distribution of coastal TWL and its components during this period by assessing (1) the relative contribution of different TWL components around the coast; (2) how extreme waves, surges, and tide interacted and if they occurred simultaneously; and (3) if this has implications in defining the severity of coastal hazard conditions. The TWL components' coastal distribution in winter 2013/4 was not constant in space, impacting differently over different regions. High ( $>90$ th percentile) waves and high surges occurred simultaneously at any tidal stage, including high tide $(7.7 \%$ of cases), but more often over the flood tide. During periods of high flood risk, a hazard proxy, defined as the sum of the sea surface height and half the significant wave height, at least doubled from average over three-quarters of the coast. These results have important implications for the risk management sector.
\end{abstract}

\section{Introduction}

High total water levels (TWLs), arising from combinations of waves, storms surges, and tides, can lead to dangerous coastal conditions (Idier et al., 2019; Vousdoukas et al., 2018; Wolf, 2009). In the UK, coastal flooding is the most threatening natural hazard for coastal communities and environment (Home Office, 2017). In 2013, it was assessed that 520000 properties in the UK (about $70 \%$ of which were homes) were in locations where the annual risk from coastal flooding was $0.5 \%$ or greater (Committee on Climate Change, 2013). The financial implications of flooding can be severe: during the exceptionally stormy winter of 2013/4 coastal flooding in the UK was estimated to cause damage amounting to a value of GBP 592.1 million (Chartteron et al., 2016). In Ireland, the extreme conditions of that winter led to high coastal erosion rates with an extreme environmental impact (SánchezArcilla et al., 2016; Cox et al., 2018; Janjić et al., 2018) and flooding, especially over the south, west, and northwest coasts (Met Éireann, 2014; Thorne, 2014); insurance claims and repairs resulting from the extreme weather damage amounted to more than EUR 210 million (Kandrot et al., 2016). One problem is that storms and floods can vary in both magnitude and distribution (Kirezci et al., 2020), making mitigation costly and difficult. For example, storm Xaver, and its associated storm surge, generated higher still water levels than ever recorded before at multiple tide gauges (TGs) around the UK coast (Spencer et al., 2015) on 5-6 December 2013. That same winter, storm Anne occurred between 
3-4 January 2014 (RMS, 2014), leading to widespread flooding along southern UK coastal regions (Haigh et al., 2015; Sibley et al., 2015). This was as a result of extreme TWL through the coincidence between the surge and spring tides (RMS, 2014; Sibley et al., 2015). Storm Ulla, also known as the "Valentine Day Storm" as it occurred on 14 February 2014, hit the UK with extreme winds (RMS, 2014) and led to some of the largest recorded skew surges over several sites in south-western UK (Haigh et al., 2017). The frequency of these kinds of event is expected to increase in the future (Stocker et al., 2013), which matters not only because the number of individual storms could augment, but also because their impact is increased by the clustering of events (Priestley et al., 2017). During winter 2013 the frequency of intense cyclones was almost twice that of the climatological average (Priestley et al., 2017), and the proximity of events increased the impact of the storms over the British Isles (Priestley et al., 2017). This, together with other factors such as the compound risk from coastal TWL and high river discharge (Khanal et al., 2019; Moftakhari et al., 2019) or the urbanisation of coastal regions (Stevens et al., 2016), may increase threats from coastal flooding (De Dominicis et al., 2020; Horsburgh et al., 2020; Stocker et al., 2013). It is therefore important to understand how the sea level components behave at the coast and interact during extreme events.

There are several processes to consider in the tide-surge, tide-waves, and surge-waves interactions. For example, both surges and tide act as shallow water waves and can modulate each other's phase, leading extreme surges to often occur over the rising tide (Horsburgh and Wilson, 2007). The interaction between non-tidal residuals and the tide can reduce extreme sea level by up to $30 \%$ (Arns et al., 2020) and is therefore a key parameter to consider when studying coastal high-water-level formation. Extreme waves are also a crucial component of TWL and can affect (and increase) surges by altering the surface roughness (Bertin et al., 2015; Idier et al., 2019). The dependence between waves and surges can double the extreme water level return period of 1 in 100 years and lead to extreme coastal conditions (Marcos et al., 2019). It is worth noting that this type of extreme value statistic can be altered by new extreme events; storm Xaver, occurred at the beginning of December 2013, has increased the highwater-level estimates for a return period of 1 in 200 years of up to $0.4 \mathrm{~m}$ in some areas of the German Bight (Dangendorf et al., 2016). Moreover, waves can be affected by tidal currents (Ardhuin et al., 2012) and by tidal water levels, with high tide and deep waters allowing waves to travel further, with less dissipation at the seabed. At low tide, this same modulation of water depth increases the bottom drag and creates a larger sink of wave energy. Excluding dissipation processes, waves travelling against the ebb current direction can increase in height and steepness (Idier et al., 2019). When these processes combine, they can lead to high coastal TWL that may be dangerous for certain areas.
In this paper we study the interactions between TWL components around the UK and Irish coasts. The focus is on offshore conditions, up to $1.5 \mathrm{~km}$ from land with a minimum depth of $10 \mathrm{~m}$, to investigate where high-water levels can occur before waves enter the surf zone. We selected winter 2013/4 as a case study, since it was an exceptionally stormy season, to investigate the coastal conditions during the extreme events of this period and the processes that lead to it. The overall aim is to analyse the spatial distribution of TWL along the UK coast during winter 2013/4, assessing the relative contributions of its major components: waves, tides, and surges. Where are the maximum waves and surges occurring during that period? Are extreme waves and surges concurring more often over specific regions? How was the coastal hazard risk affected by the conditions of that winter?

The methodologies and the extreme period selected are described in Sect. 2. Results can be found in Sect. 3 and are discussed in Sect. 4. The final conclusions are found in Sect. 5.

\section{Methodology}

The winter of 2013/4 is renowned for being a particularly extreme winter in terms of TWLs (Wadey et al., 2014) and is therefore an interesting period to investigate. To set the context of conditions during winter 2013/4, we first apply the peak-over-threshold (POT) method (Coles, 2001) to a long-term wave model climatology. The 90th percentile of the significant wave height $\left(H_{\mathrm{s}}\right)$ from December 2013, January, and February 2014 is compared to the 90th percentile of a 37-year (1979 to 2015) climatological run of the Wave Watch III model (WW3; Tolman and Iii, 2014), at $1 / 12^{\circ}$ (approximately $9 \mathrm{~km}$ ) resolution. We repeated this analysis to evaluate the relative magnitude of the surges during this period. The 90th percentile of the surge during winter 2013/4 was compared to that of a 27-year dataset from 1992 to 2019 using a combination of the tide-surge continental shelf models CS3 (Flather, 2000) and CS3X (Williams and Horsburgh, 2013) simulations, both with a resolution of $1 / 9^{\circ}$ in latitude and $1 / 6^{\circ}$ in longitude (approximately $12 \mathrm{~km}$ ).

To analyse the spatial distribution of TWL components during extreme events in 2013/4, simulations from the highresolution wave-ocean-atmosphere regional coupled model UKC4 (Lewis et al., 2019a, b, 2018) were used. This is a state-of-the-art coupled model which integrates WW3, the ocean model Nucleus for European Modelling of the Ocean (NEMO; Madec and the NEMO Team, 2008), and the atmospheric Unified Model (UM; Cullen, 1993). This model also allows the coupling to a river model; however in this configuration climatological river inputs are used instead. The UKC4 coupled system is aimed at replacing parameterisations with direct coupling, to more explicitly simulate feedbacks between waves, ocean, and atmosphere at scales that are relevant to coastal interactions. The ocean component $(\mathrm{NEMO})$ uses a regular high-resolution $(1.5 \mathrm{~km})$ grid, ini- 
tialised from an operational hindcast simulation of the Atlantic Margin Model (AMM15; Graham et al., 2018). The daily lateral boundary conditions are obtained from the operational $12 \mathrm{~km}$ resolution NAT12 North Atlantic ocean model configuration (Siddorn et al., 2016). The atmosphere component (UM) overlaps with the ocean grid over the shelf region at $1.5 \mathrm{~km}$ resolution, increasing to $4 \mathrm{~km}$ resolution at the domain's edges. It is initialised on 30 October 2013 from a global MetUM operational simulation at $25 \mathrm{~km}$ resolution (Lewis et al., 2019a). The Wave component (WW3) is run on a two-tier multiple cell grid ( $\mathrm{Li}, 2011)$ varying from a resolution of approximately $3 \mathrm{~km}$ in water deeper than $40 \mathrm{~m}$ (open waters) to $1.5 \mathrm{~km}$ resolution in coastal regions. It is initialised by a $10 \mathrm{~d}$ uncoupled simulation of the wave model (WW3), while the lateral boundary conditions are provided hourly from a hindcast wave-only simulation of the same model (Lewis et al., 2019a). There is a two-way hourly coupling set up between all of the system's components; this is achieved through the OASIS_MCT libraries (Valcke et al., 2015). A more in depth description of the model set-up can be found in Lewis et al. (2019a, b, 2018) and Valiente et al. (2021). The model in its fully coupled configuration is applied from 1 December 2013 to 28 February 2014, outputting hourly data at each point (see Fig. 1 for the domain). Here, we focus on the coast and consequently used the first grid cell from every land point in the domain (Fig. 1). Note that because the resolution is $1.5 \mathrm{~km}$ this area is as close to the coast as possible; however some nearshore effects will not be represented in the model. Shallow water dynamics as well as the tidal asymmetry and modulation of high waters in intertidal estuaries (Nidzieko, 2010) could lead to changes in the timing of waves, surges, and tide inshore which cannot be represented here. For example, the model will not simulate flooding and drying, and wind waves represent an "offshore" condition without shallow water transformation. The modelled $H_{\mathrm{s}}$ and sea surface height (SSH), including astronomical tides and surges, are extracted from the fully coupled simulation. To derive the surge from the SSH, information on the tide's behaviour without the influence of the atmospheric component is needed. This baseline signal is obtained from a tide-only simulation of the UKC4 over the same period as the fully coupled run. Data are used to calculate the non-tidal residual by subtracting the baseline from the SSH.

The model predictions were compared against observations for validation; the $\mathrm{SSH}$ is compared to values from 25 TGs located around the UK coast during the period between 1 December 2013 and 28 February 2014. These data are obtained from the British Oceanographic Data Centre (BODC; see data availability section). The model baseline tide is compared to the tide obtained from harmonic analysis of the TGs during the same period. Results from this comparison are shown in Appendix A (Tables A1 and A2). For the TWL comparison, the absolute difference between model and observation is $0.31 \mathrm{~m}$, the RMSE is $0.37 \mathrm{~m}$, and the correlation $R$ is 0.98 . For the tide comparison the absolute mean

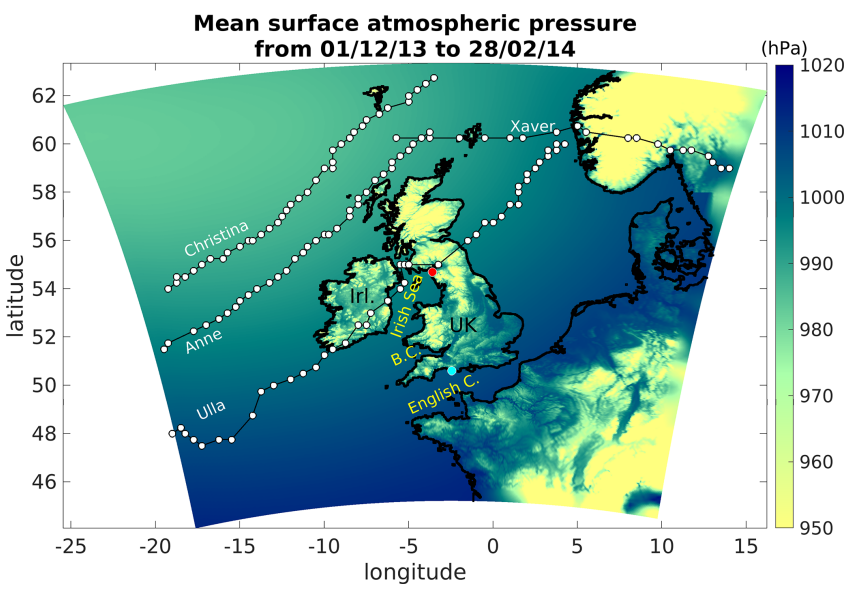

Figure 1. The UKC4 model domain with shading giving the UKC4 simulated mean surface atmospheric pressure during the 3 months of winter 2013/4. The figure also shows the estimated track of four storms during winter 2013 (storms Xaver 5 December 2013, Anne 3 January 2014, Christina 7 January 2014, and Ulla 14 February 2014). Tracks are obtained from the mean sea level pressure (MSLP) of hourly ERA5 reanalysis data. The white markers show the location of hourly minimum MSLP during the storm period. The red and blue dots show the locations of Solway Firth and Weymouth respectively, which are mentioned in the discussion.

difference is $0.30 \mathrm{~m}$, the RMSE is $0.35 \mathrm{~m}$, and the correlation is 0.99 .

A key goal was to investigate the different contributions to coastal extreme water levels caused by waves, surges, and tides. To do this, for each coastal point, individual storms were first identified, by separating high-wave events where there is more than $12 \mathrm{~h}$ between successive peaks. Once these separate events were identified, the most intense storms were selected by ranking the $H_{\mathrm{s}}$ peaks and considering the 10 highest $H_{\mathrm{s}}$ values. The $24 \mathrm{~h}$ interval around each peak is then considered to represent a storm period. During these storm periods, we select the maximum $H_{\mathrm{s}}$, surge, and tide value at each point in space, independently from the time they occurred at. The objective is to show which area was impacted more severely by each component.

To understand how the TWL components are distributed in time with respect to each other, we estimated the number of extreme $H_{\mathrm{s}}$ and surges occurring over each hour of the tidal cycle (see the schematic in Fig. 2); this is expressed as a percentage of the total number of extreme $H_{\mathrm{s}}$ and surges that occurred during winter 2013/4. To do this, the first step was to calculate the 90th percentile of $H_{\mathrm{s}}$ and surges over the entire winter. During the storm periods chosen, all the hourly model outputs higher than the 90th percentile value were selected. We then found the closest tidal peak to each of these outputs, to investigate which tidal stage the extreme $H_{\mathrm{s}}$ or surge occurred on, from $6 \mathrm{~h}$ before to $6 \mathrm{~h}$ after high tide. The number of high $H_{\mathrm{s}}$ and surges occurring over each stage of the tide were counted. This number was converted 
to a percentage of the total number of individual high $H_{\mathrm{S}}$ and surges or simultaneous $H_{\mathrm{s}}$ and surges considered overall at each point. For example, if 10 extreme $H_{\mathrm{s}}$ occur at one point at any time during winter 2013/4 and two of these occur at high tide, we show that $20 \%$ of extreme $H_{\mathrm{s}}$ occurred at high tide. The mean of this percentage at all coastal points is calculated for each hour of the tidal cycle with the respective standard deviation (SD). Note that "simultaneous" refers to high $H_{\mathrm{S}}$ and surge data outputted during the same hour. We also show the spatial distribution of the number of simultaneous extreme $H_{\mathrm{s}}$ and surges at high tide, as well as the differences between the latter and the values for low tide, $3 \mathrm{~h}$ before high tide and $3 \mathrm{~h}$ after high tide. This allows us to better understand the interactions between extreme $H_{\mathrm{s}}$, surges, and tides during winter 2013/4.

To understand how the joint contribution of waves, surges, and tides affected the coastal hazard under these conditions, a hazard proxy (HP) was defined as $\mathrm{SSH}+1 / 2 H_{\mathrm{s}}$, and this was calculated for each coastal point. This HP has been used in previous publications (e.g. Lyddon et al., 2019) under the premise that operationally flood warnings are issued when predefined thresholds, based on water level and waves, are exceeded (Del Río et al., 2012; Lawless et al., 2016). While different regions have a different threshold for operational purposes as they are, this proxy is used in this study to provide a national-scale picture to visualise how the severity of conditions varies around the UK coast. The HP is calculated for all time in which the tide is higher than the lowest high water, similar to the approach of Lyddon et al. (2019), to focus on conditions in which overtopping is most likely.

All processed model data used in the study are made available via Zenodo (see Sect. "Code and data availability").

\section{Results}

Our results show that during winter 2013/4 extreme wave and surge events are higher than in a typical year, with the $H_{\mathrm{s}}$ 90th percentile of that period on average $35 \%$ higher than that of the 37-year climatology from 1979 to 2015 (Fig. 3) and the surge 90th percentile on average $106 \%$ higher than that of the period from 1992 to 2019 (Fig. 4).

To study this extreme period and the conditions that characterised it, the waves, surges, and tide simulated in the UKC4 regional coupled system are considered separately. The spatial distribution of their maximum values (Fig. 5) shows that each component of the TWL is not evenly distributed around the UK coast. The highest $H_{\mathrm{s}}$ can be seen along stretches of coastlines exposed to the Atlantic, including the south-west and north-west UK and the west coast of Ireland, where $H_{\mathrm{s}}$ reached up to $14.1 \mathrm{~m}$. The highest surges, reaching up to $2.7 \mathrm{~m}$ in Solway Firth, impacted the west coast of England and Scotland, especially in the north-east Irish Sea and in the Bristol Channel. They were also dominant along the south-east coast of England. Independent of the storm events, astronomical tides are larger in the eastern Irish Sea, in the English Channel, and in the Bristol Channel, where they reach up to $8 \mathrm{~m}$. These maxima are given independently from the time at which they occur and therefore show which regions are affected more by each component but do not show if and how these extremes interacted together.

To better understand the interaction between the water level components, the timing of high $H_{\mathrm{s}}$, surge, and tide is analysed (Figs. 6 and 7). The percentage of extreme $H_{\mathrm{s}}$ and surges occurring over each hour of the tidal cycle is calculated relative to the total number of extreme $H_{\mathrm{s}}$ and surges during winter 2013/4. Results show that high $H_{\mathrm{s}}$ occurred more often near high tide, with up to $8.3 \%$ (SD 1.5\%) of events $1 \mathrm{~h}$ before the high-water peak, while the high surges were found more often half-way through the flood tide, with $9 \%$ (SD $4 \%$ and SD $3.4 \%$ ) of events occurring 3 and $2 \mathrm{~h}$ before high tide, followed by $8.7 \%$ (SD $2.4 \%$ ) of events $4 \mathrm{~h}$ before high tide (Fig. 6). There is a clear pattern in both $H_{\mathrm{s}}$ and surge curves (Fig. 6), with more extreme $H_{\mathrm{S}}$ and surges occurring over the flood tide than over the rest of the tidal cycle, although this signal is more pronounced in surges than waves. The pattern of the curve representing simultaneous $H_{\mathrm{s}}$ and surges is a combination of those signals, with a dominant influence from the surges. Simultaneous events occurred over each stage of the tidal cycle, but more often during the flood tide, with $9 \%$ (SD $6.6 \%$ ) and $8.9 \%$ (SD $5.1 \%$ ) of events occurring 2 and $3 \mathrm{~h}$ before high tide. High $H_{\mathrm{S}}$ and surges also occurred at high tide, with $8.3 \%$ (SD $1.5 \%$ ) of $H_{\mathrm{s}}, 7.8 \%$ (SD $2.2 \%$ ) of surges, and $7.7 \%$ (SD $3.6 \%$ ) of the simultaneous events happening within the hour of high tide. Looking at the distribution of events at the coast (Fig. 7) some areas also have an increase in simultaneous events throughout the ebb tide. A higher number of simultaneous events is recorded over the western and southern coast of the UK, with up to $21 \mathrm{~h}$ of concurring $H_{\mathrm{s}}$ and surges recorded in proximity of Weymouth $2 \mathrm{~h}$ after high tide. In the same region, $20 \mathrm{~h}$ of simultaneous extreme $H_{\mathrm{s}}$ and surges are also recorded over the flood tide. These are not necessarily consecutive hours and could indicate multiple storms hitting the area. During the period of coincidence between extreme waves, extreme surges, and high tides, the regions showing the highest TWLs are over the west of Ireland, Scotland, and in the Bristol Channel, followed by the north-west and south-east of England.

The implications of these simultaneous events can be quantified in terms of a coastal hazard mean and maximum HP value for each region of the coast during periods in which overtopping is considered more likely (Fig. 8). This value, similarly to the TWL, represents the simultaneous contribution to the water level from waves, surges, and tides. However, operational thresholds are not based on just the maximum values of the TWL but are set considering extreme conditions; therefore the HP is calculated from the SSH (including astronomical tides and surges) summed to only half of the $H_{\mathrm{s}}$ rather than the maximum. The calculation shows that the mean HP over all coastal points in the model domain 


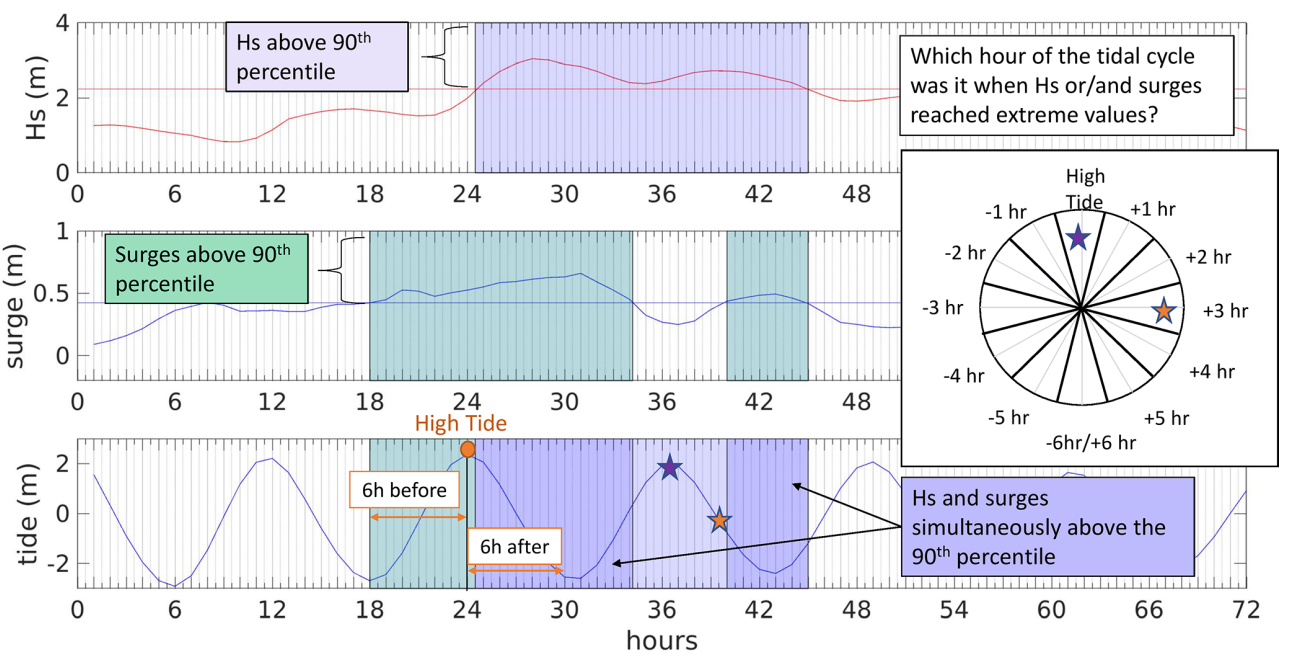

Figure 2. Schematic example explaining the methodology used to evaluate the number of extreme $H_{\mathrm{S}}$ and surges with respect to the tidal cycle. This example shows $3 \mathrm{~d}$ of the time series at one coastal point. The $H_{\mathrm{s}}$ values higher than the 90th percentile (calculated over 3 months of data at the same point) are considered high. The closest tidal peak to each value is found. We then evaluate when each value occurred in the tidal cycle, from $6 \mathrm{~h}$ before to $6 \mathrm{~h}$ after high tide. The same is done for surges and for cases in which $H_{\mathrm{S}}$ and surges are simultaneously higher than the respective 90th percentile. The two stars indicate examples where the extreme $H_{\mathrm{S}}$ occurred at high tide and $3 \mathrm{~h}$ after high tide.

(a) mean 90th percentile Hs 1979-2015

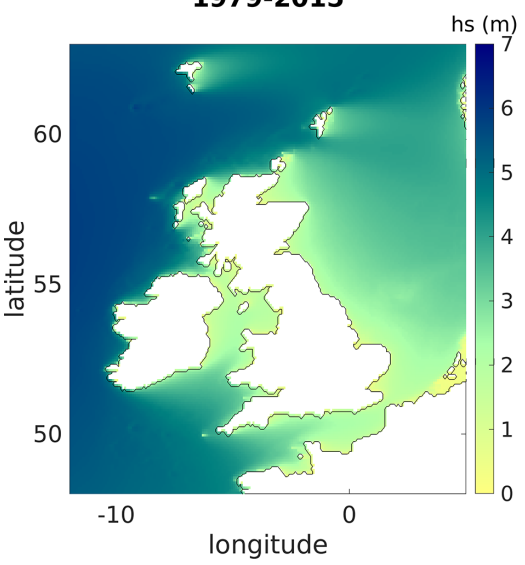

(b) increase in 90th percentile winter 2013-2014 vs 1979-2015

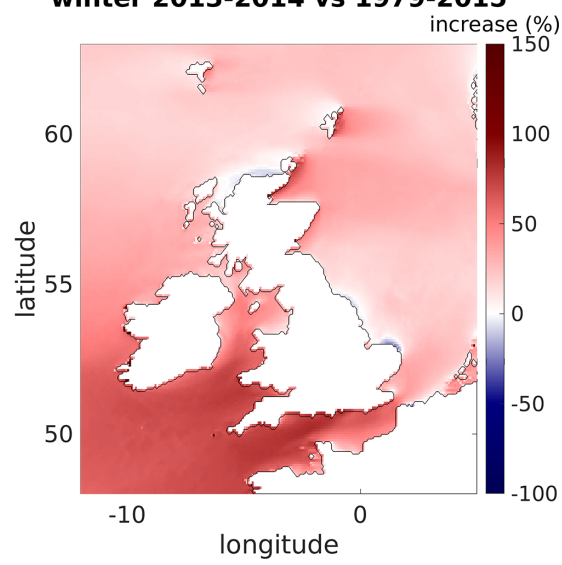

Figure 3. Mean of the $H_{\mathrm{S}}$ 's 90 th percentile from the climatology run (a). Percentage increase in $H_{\mathrm{S}}$ in winter 2013/4 compared to climatology (1979-2015) derived from WW3 simulation (b). Note the skewed colour range and that in some areas of the UK east coast and north of Scotland the $H_{\mathrm{s}}$ in Fig. 3 does reduce.

is $1.8 \mathrm{~m}$, ranging from $-0.18 \mathrm{~m}$ in the Faroe Islands to $4.9 \mathrm{~m}$ in the Bristol Channel. The maxima in HPs are found at the west coast of Scotland, Ireland, north-west of England, and the Bristol Channel, where values reach $8.8 \mathrm{~m}$ in areas where the average HP is $4.3 \mathrm{~m}$. The maximum HP is above $3 \mathrm{~m}$ over more than $80 \%$ of the coast. This includes regions of the east coast of UK that are affected by a lower number of extreme $H_{\mathrm{S}}$ and surges compared to the west and south coasts. The increase in the HP from the average value to the maximum recorded that winter shows that the water level during the most threatening times more than doubled over $75 \%$ of the British and Irish coasts combined.

\section{Discussion}

From a high-resolution regional coupled model simulation of winter 2013/4, it is possible to analyse the dominant factors driving high coastal TWL around the UK. It is important to underline that this study does not show a return period of events and cannot show which areas of the UK have higher flood risk. Rather, it provides a case study of extreme conditions to better understand the processes related to the formation of high coastal TWLs. Considering the maximum $H_{\mathrm{s}}$, surges, and tides individually (Fig. 5), we showed that some areas of the UK are dominated by specific compo- 

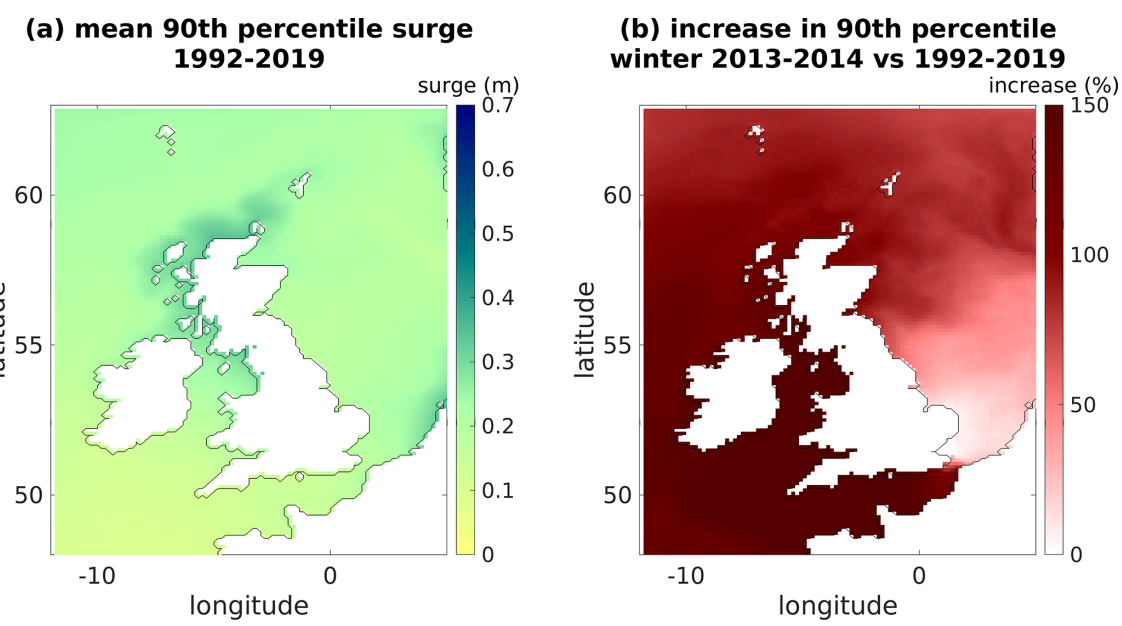

Figure 4. Mean of the surge 90th percentile from the climatology run (a). Percentage increase in surge in winter 2013/4 compared to climatology data (1992-20019) from CS3 (1992-2006) and CS3X (2007-2019) simulations (b). Note that the colour scales are different between Figs. 3-4.
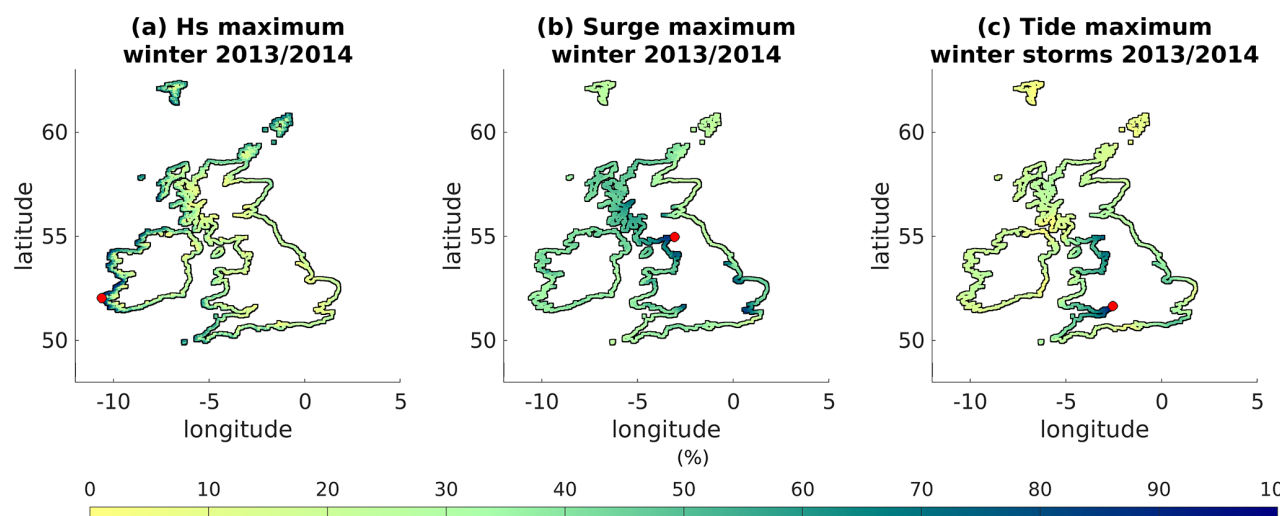

$30 \quad 40$

$50 \quad 60$

Figure 5. Spatial distribution of the UKC4-simulated maximum $H_{\mathrm{S}}$ (a), surge (b), and tide (c) that occurred during winter 2013/4. Maxima are given for each coastal point independently of when they occur. Values are expressed as a percentage of the respective overall maximum found over the entire coast in winter 2013/4: these are $14.1 \mathrm{~m}$ for $H_{\mathrm{s}}, 2.7 \mathrm{~m}$ for surges, and $8 \mathrm{~m}$ for the tide. They are indicated by the red dot. Note that values in some areas seemingly change with distance from the coast (e.g. $H_{\mathrm{s}}$ in the west of Ireland); this is because the coastal geomorphology is quite complex in those regions, and the high resolution of the model leads to values changing drastically over short spaces. Only the closest grid cell to the coast is used.

nents of the TWL during winter 2013/4. The climatology run compared to the maximum surges and waves shows that the highest residuals are distributed over the north-west and south-west coasts of England, while the highest $H_{\mathrm{s}}$ values are distributed over the regions open to the Atlantic Ocean. Therefore, different types of hazards affected each area. This implies that in a changing climate, it is important to consider not only the TWL overall but also the different hazards coming from each component. Regions that have been at risk because of strong winds with wave breakers set up as defences might become affected by surges or tides, which require a different approach. During winter 2013/4, a sequence of extreme storms induced by an unusually strong North Atlantic jet stream (RMS, 2014) followed a more southerly path than usual (Thorne, 2014), causing extended flooding over the north of Scotland, west of Wales, west, south-west, and south-east of England (Haigh et al., 2016; RMS, 2014; Thorne, 2014). The extent of storms over that season leads to the question of whether the ongoing changes in the climate and typical storm conditions may also lead to changes in the spatial distribution and duration of floods (Thorne, 2014).

The interaction between $H_{\mathrm{s}}$, surges, and tides is the main driver of high TWL. If the maximum waves, surges, and tide (Fig. 5) could occur simultaneously, the highest TWLs would reach above $16 \mathrm{~m}$ in areas of the west of Ireland and $13 \mathrm{~m}$ in areas of the Bristol Channel. It is therefore important to understand if extreme values from each component could happen simultaneously and, if not, which could be the worst- 

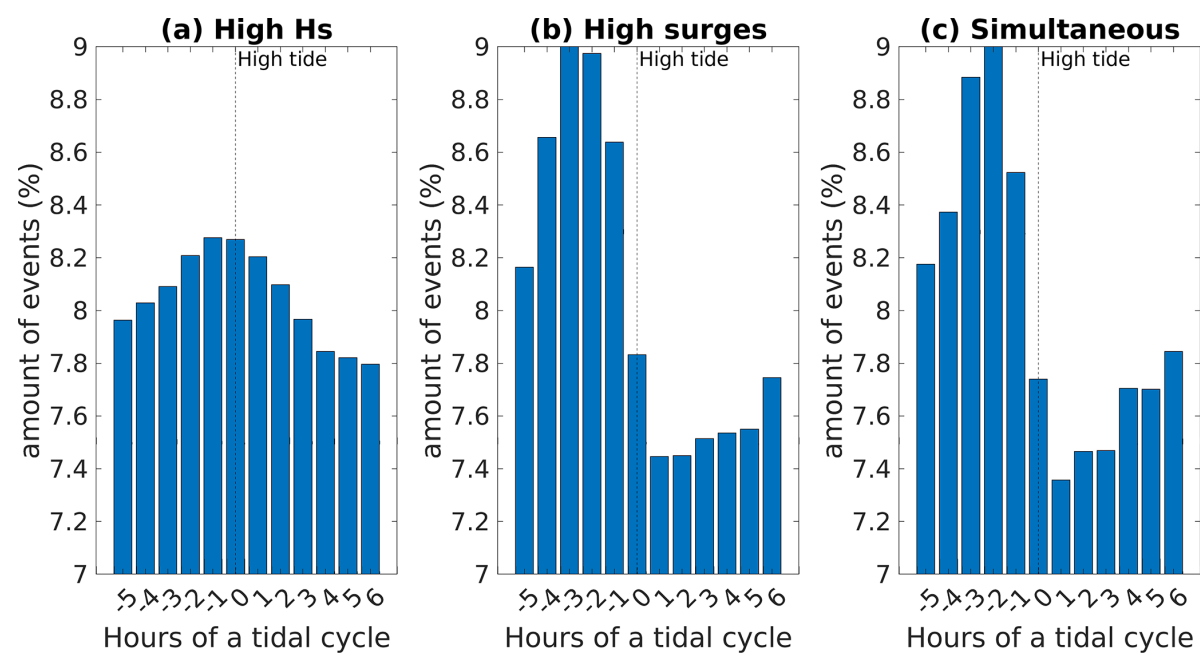

Figure 6. Percentage of the high ( $>$ 90th percentile) $H_{\mathrm{S}}$ (a) and surges (b) occurring as a function of tidal cycle stage during winter 2013/4 storm events. Percentage of simultaneous events shows when both $H_{\mathrm{S}}$ and surges are within the upper 90th percentile concurrently (c).

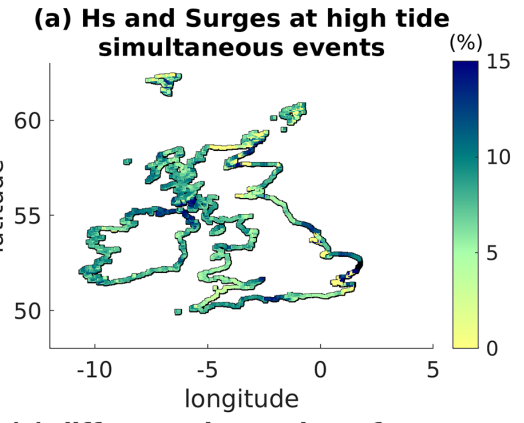

(c) difference in number of events $3 \mathrm{~h}$ before high tide - high tide

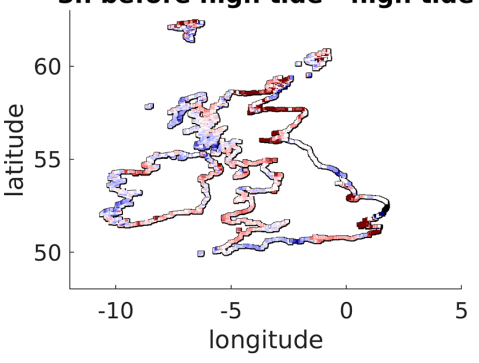

(b) difference in number of events

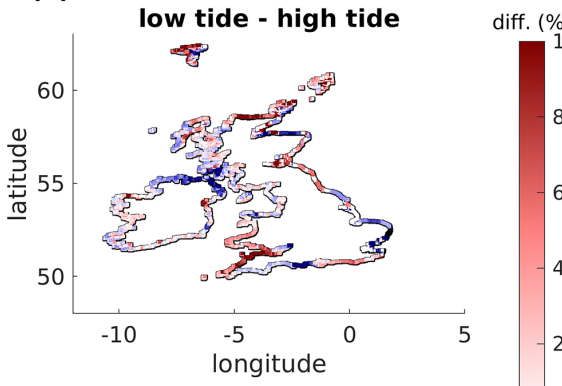

(d) difference in number of events 3h after high tide - high tide

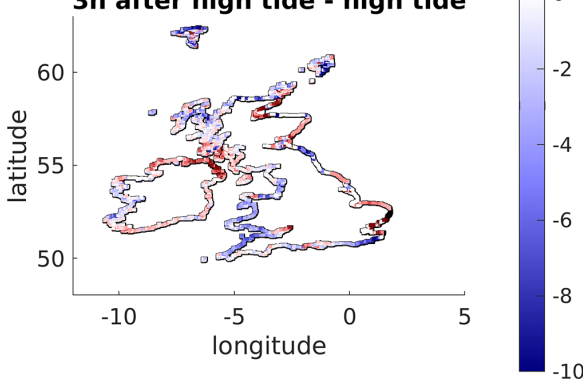

Figure 7. Number of hours in which high (above 90th percentile) $H_{\mathrm{S}}$ and surge concur within $1 \mathrm{~h}$ of high tide (a). This number is shown as a percentage of the total number of simultaneous events recorded during the winter at each location. The plot also shows the differences between the percentage of events occurring at high tide and those occurring at low tide (b), $3 \mathrm{~h}$ before high tide (c) and $3 \mathrm{~h}$ after high tide (d). This shows how the simultaneous events are distributed over the tidal cycle.

case scenarios. A previous study shows that most extreme sea level events are strongly dependent on the tidal stage over which they occur (Haigh et al., 2016). During winter 2013/4, high (more than the 90th percentile) surges occurred more often halfway through the rising tide, $3-4 \mathrm{~h}$ before high tide (Fig. 6). This is consistent with previous observational studies finding that the peak surges tend to appear $3-5 \mathrm{~h}$ before high tide (Horsburgh and Wilson, 2007). This is because surge and tide, behaving like two shallow water waves, mu- tually affect each other's phase as a function of water depth (Horsburgh and Wilson, 2007; Rossiter, 1961).

The results in Fig. 6 also show a higher percentage of extreme waves occurring in the hours before high tide. It should be noted that the coastal region in the model domain is defined as the first $1.5 \mathrm{~km}$ from land, which has a minimum depth set at $10 \mathrm{~m}$. Wind waves in this area are all deep-water waves (or in some rare cases intermediate-water waves). The coastal water depth does not directly impact 


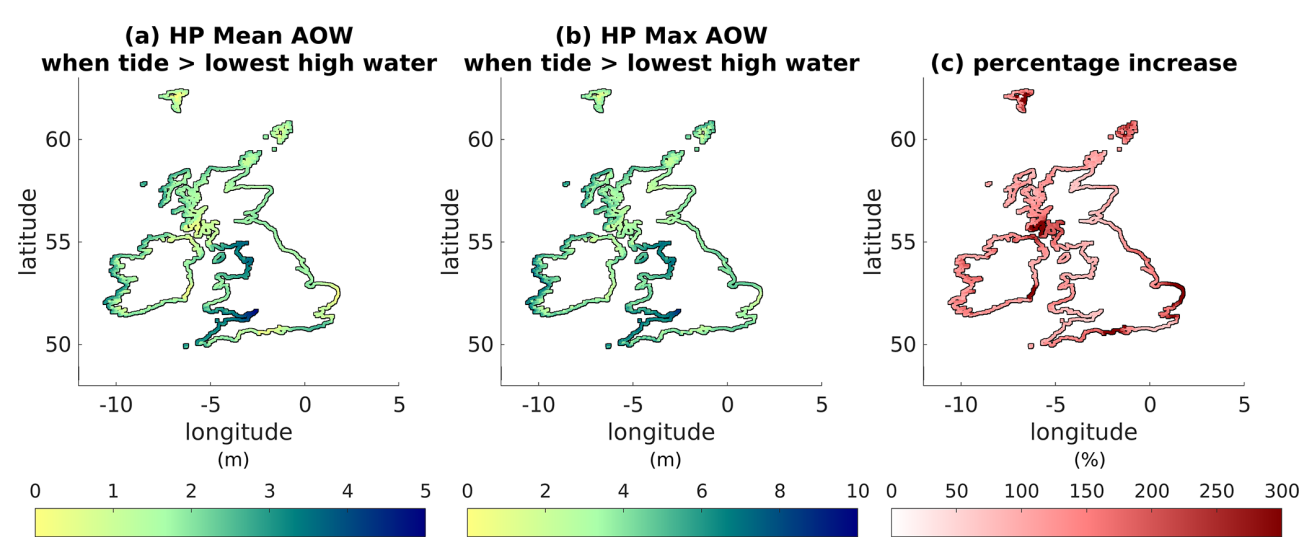

Figure 8. Mean and maximum hazard proxy calculated at each coastal point $(\mathbf{a}, \mathbf{b})$ and percentage increase between the mean and maximum (c). Note that the percentage increase plot was saturated to zero to only focus the positive increase; some regions of the Faroe Islands showed a decrease. Also note that this is the mean of values for winter 2013/4, which is an extreme period; the comparison to a longer climatology simulation could show a higher increase.

them, but changes in tidal currents, wind, and low-pressure system will affect them. Resolving the surf-zone processes, essential for operational flood-hazard studies, would require higher-resolution model studies. However, our results show accurate near-shore conditions that could be used as input to drive higher-resolution flood models for further studies of specific regions. Moreover, our study did not investigate the magnitude of waves and surges per se but rather the recurrence of extreme values over the tidal cycle. Other studies focusing on the period January-February 2014 show that, in some regions of the Irish Sea, the tide-wave interaction, including tidal-current-induced modulation of wave refraction, can lead to an increase in the magnitude of $H_{\mathrm{s}}$ (Lewis et al., 2019 c). Larger waves during high water were demonstrated to be up to $20 \%$ larger because of the interaction with the tide. In the context of our study, this means that in some cases extreme waves could not only occur more often near high tide, but also be higher during this period because of the very interaction with high waters.

Due to a combination of the processes described above, simultaneous high $H_{\mathrm{s}}$ and surges occur more often 2 to $3 \mathrm{~h}$ before high tide and rarely at high water (Fig. 7). From observational studies the residual peak has been shown to rarely occur within an hour of high tide (Horsburgh and Wilson, 2007), which is consistent with these coupled model results. However, results also show that it is possible for all three components of the TWL to reach peak values simultaneously in $7.7 \%$ of cases considered with a SD of $3.6 \%$. This means that in most coastal points at least $4.1 \%$ of extreme waves and surges concurred at high tide. The coupled model data also show that $7.8 \%$ of events concurred at low tide (Figs. 6 and 7). In this case simultaneous high surge and $H_{\mathrm{s}}$ are not a threat since they occur over low tide, and no observed skew surge event during winter 2013/4 coincided with extreme sea level events at low tide (Haigh et al., 2016).
Observational studies linked extreme sea level events occurring along the south-western England coast with storms travelling to the north of the UK (Dhoop and Mason, 2018; Haigh et al., 2016), with centres located west or north-west of Ireland, north of Scotland, or around Scandinavia (Haigh et al., 2016). This is consistent with the atmospheric model outputs from this coupled simulation (Fig. 1) and with the majority of extreme simultaneous events being simulated over the west coast and south-west coast of the UK (Fig. 7). This area was affected by several flood events during that period (Haigh et al., 2016), which underlines the importance of tide-wave-surge interactions. In areas such as the west coast of Ireland, where the highest $H_{\mathrm{s}}$ values are recorded but high waves do not often concur with surges, the same TWL values can be obtained as for other areas with lower waves and simultaneous high surges or tides. Both cases can represent a different kind of threat for a given coastal area. These results suggest the need for further analysis of the relative contribution to TWL from wave tides and surges in subsections of the coast to understand if it can be representative of specific regions, considering the influence of storm tracks and duration in more detail.

When considering periods during which overtopping is more likely, the HP reaches on average above $1.8 \mathrm{~m}$ across the UK and Irish coasts, but the maximum HP (Fig. 8) reaches at least $3 \mathrm{~m}$ over more than $80 \%$ of the coastal region considered. The HP reached above $6 \mathrm{~m}$ over the coast of the north-east Irish Sea and the Bristol Channel, where peak surges are dominant, as well as over the west of Ireland, where extreme waves are dominant. This shows that each of the TWL components should be considered when trying to assess coastal hazard since each of them can lead to hazardous conditions in particular circumstances. Note that this HP cannot give information as to whether a region is more at risk of flooding than another but gives an understanding of how the TWL distribution can change at the coast during 
extreme periods at risk of flooding. The operational coastal risk levels are individual to each region, which will have different flood hazard thresholds depending on local conditions (bathymetry, geomorphology, etc.). However, results show that the maximum increase in HP from the mean at least doubled over three-quarters of the UK coastline. For a quarter of coastal points the HP values increased more than $160 \%$. This is an increase from an average value calculated from an extreme winter, which means that the value will underestimate the increase from a typical winter condition.

In the future it would be interesting to consider individual storm events to focus on the importance of the storm tracks and storm timing over the distribution of coastal water levels, exploiting the coupling flexibility of the UKC4 system to study sensitivity to factors such as the atmospheric forcing. Moreover, observational studies showed that the average storm duration from climatological records can be very different over the east and west coast of the UK, with increased likelihood of high waves coinciding with high waters over the west coast where storms are on average longer (Dhoop and Mason, 2018). It would be interesting to consider the duration of these events in future studies to understand if several smaller storms could lead to a threat similar to that of a longer storm.

\section{Conclusions}

In this paper we have undertaken an analysis of the coastal spatial distribution of TWL and its major components: waves, tides, and surges. A consistent analysis of these components is enabled by considering results of fully coupled wave-ocean-atmosphere coupled regional model simulations. Results showed that during the extreme winter of 2013/4, the highest simulated waves impacted over the Atlantic coast, while surges were dominant over the north-west coast of England, in the Bristol Channel, and south-west of the UK. The tide was dominant in the north-west of England, Bristol Channel, and English Channel. Results show that each of these components individually can lead to high coastal water levels and should all be considered when assessing severe coastal conditions. The overall highest $H_{\mathrm{s}}$, surge, and tide are respectively 14.1, 2.7, and $8 \mathrm{~m}$. During that winter, extreme surges and $H_{\mathrm{s}}$ occurred individually and simultaneously over each stage of the tide. Most concurrent events are found 2 to $3 \mathrm{~h}$ before high tide. There are more simultaneous high $H_{\mathrm{s}}$ and surges over the west and south-west coast due to the storm tracks of that period travelling north of the UK. However, the maximum HP can be significant everywhere in Britain. The HP during hazardous periods at least doubled over three-quarters of the coastal points in the UK and Ireland. This suggests that other factors could have an important impact in determining the hazard of a specific region, as for example the duration and track of storms which should be investigated in future studies. Results also showed that during the extreme 2013/4 winter, it was possible for extreme $H_{\mathrm{s}}$, surges, and tide to occur simultaneously, leading to extremely dangerous coastal conditions.

\section{Appendix A}

Table A1. Comparison of TWL to TGs from 1 December 2013 to 28 February 2014. To assess against observations with a higher temporal frequency than model outputs, both the TG and the model data are interpolated to $1 \mathrm{~min}$ time series and then re-averaged within the hour. In some cases, we found an offset of $1 \mathrm{~h}$ in the peak time from model and observation. The percentage of peaks misrepresented by the model is shown in the last column. In nearly all these cases the model peaks occur $1 \mathrm{~h}$ earlier than in observations. The columns show the TG site names, the mean absolute difference between the model minus the TG (MD), the root-mean-square error (RMSE), the correlation $(R)$, the mean peak magnitude difference (MPD), and the number of cases in which the model peaks were offset in time compared to that of TGs, i.e. the peak time difference (PTD).

\begin{tabular}{lrrrrr}
\hline TG site & $\begin{array}{r}\text { MD } \\
(\mathrm{m})\end{array}$ & $\begin{array}{r}\text { RMSE } \\
(\mathrm{m})\end{array}$ & $R$ & $\begin{array}{r}\text { MPD } \\
(\mathrm{m})\end{array}$ & $\begin{array}{r}\text { PTD } \\
(\%)\end{array}$ \\
\hline Aberdeen & 0.26 & 0.32 & 0.98 & -0.08 & 32.76 \\
Barmouth & 0.18 & 0.23 & 0.99 & -0.09 & 24.71 \\
Cromer & 0.48 & 0.53 & 0.99 & -0.24 & 5.75 \\
Devonport & 0.28 & 0.33 & 0.99 & -0.27 & 30.46 \\
Dover & 0.41 & 0.48 & 0.99 & -0.12 & 2.87 \\
Fishguard & 0.22 & 0.24 & 0.99 & -0.21 & 4.02 \\
Heysham & 0.47 & 0.62 & 0.97 & 0.26 & 7.47 \\
Hinkley & 0.27 & 0.34 & 0.99 & -0.18 & 14.37 \\
Holyhead & 0.22 & 0.25 & 0.99 & -0.23 & 14.94 \\
Ilfracombe & 0.28 & 0.34 & 0.99 & -0.32 & 13.79 \\
Kinlochbervie & 0.12 & 0.15 & 0.99 & -0.01 & 21.84 \\
Leith & 0.34 & 0.41 & 0.98 & -0.14 & 31.21 \\
Liverpool & 0.27 & 0.32 & 0.99 & -0.07 & 29.89 \\
LiverpoolTG & 0.27 & 0.32 & 0.99 & -0.07 & 29.89 \\
Llandudno & 0.20 & 0.25 & 1.00 & -0.06 & 6.90 \\
Lowestoft & 0.48 & 0.50 & 0.97 & -0.44 & 32.76 \\
Milford & 0.24 & 0.29 & 0.99 & -0.29 & 9.77 \\
Mumbles & 0.25 & 0.36 & 0.99 & -0.21 & 10.92 \\
Newhaven & 0.30 & 0.34 & 0.99 & -0.22 & 1.15 \\
Newlyn & 0.64 & 0.95 & 0.83 & -0.28 & 48.28 \\
Newport & 0.52 & 0.62 & 0.98 & 0.17 & 17.82 \\
StMarys & 0.32 & 0.35 & 0.99 & -0.31 & 3.45 \\
Tobermory & 0.13 & 0.16 & 0.99 & 0.00 & 18.97 \\
Ullapool & 0.13 & 0.16 & 0.99 & -0.03 & 20.11 \\
Whitby & 0.38 & 0.45 & 0.99 & -0.23 & 25.29 \\
\hline Mean total & 0.31 & 0.37 & 0.98 & -0.15 & 18.37 \\
\hline & & & & & \\
\hline
\end{tabular}


Table A2. Comparison of tide to TGs from 1 December 2013 to 28 February 2014. To assess against observations with a higher temporal frequency than model outputs, both the TG and the model data are interpolated to $1 \mathrm{~min}$ time series and then re-averaged within the hour. In some cases, we found an offset of $1 \mathrm{~h}$ in the peak time from model and observation. The percentage of peaks misrepresented by the model is shown in the last column. In nearly all these cases the model peaks occur $1 \mathrm{~h}$ earlier than in observations. The columns show the TG site names, the mean absolute difference between the model minus the TG (MD), the root-mean-square error (RMSE), the correlation $(R)$, the mean peak magnitude difference (MPD), and the number of cases in which the model peaks were offset in time compared to that of TGs, i.e. the peak time difference (PTD).

\begin{tabular}{lcrrrr}
\hline TG site & $\begin{array}{r}\text { MD } \\
(\mathrm{m})\end{array}$ & $\begin{array}{r}\text { RMSE } \\
(\mathrm{m})\end{array}$ & $R$ & $\begin{array}{r}\text { MPD } \\
(\mathrm{m})\end{array}$ & $\begin{array}{r}\text { PTD } \\
(\%)\end{array}$ \\
\hline Aberdeen & 0.28 & 0.35 & 0.98 & -0.06 & 37.93 \\
Barmouth & 0.20 & 0.23 & 0.99 & -0.07 & 27.01 \\
Cromer & 0.15 & 0.19 & 0.99 & 0.12 & 8.05 \\
Devonport & 0.33 & 0.38 & 0.98 & -0.28 & 34.48 \\
Dover & 0.22 & 0.26 & 0.99 & 0.28 & 6.32 \\
Fishguard & 0.34 & 0.37 & 0.99 & -0.26 & 6.90 \\
Heysham & 0.50 & 0.65 & 0.96 & 0.39 & 2.30 \\
Hinkley & 0.26 & 0.32 & 0.99 & -0.03 & 12.07 \\
Holyhead & 0.35 & 0.39 & 0.99 & -0.29 & 22.99 \\
Ilfracombe & 0.31 & 0.37 & 0.99 & -0.24 & 16.09 \\
Kinlochbervie & 0.29 & 0.32 & 0.99 & -0.20 & 25.86 \\
Leith & 0.38 & 0.45 & 0.99 & -0.18 & 23.70 \\
Liverpool & 0.22 & 0.27 & 0.99 & 0.11 & 28.16 \\
LiverpoolTG & 0.22 & 0.27 & 0.99 & 0.11 & 27.59 \\
Llandudno & 0.26 & 0.31 & 1.00 & -0.05 & 12.64 \\
Lowestoft & 0.10 & 0.12 & 0.98 & -0.01 & 39.08 \\
Milford & 0.36 & 0.40 & 0.99 & -0.35 & 13.79 \\
Mumbles & 0.29 & 0.35 & 0.99 & -0.18 & 13.79 \\
Newhaven & 0.18 & 0.23 & 0.99 & 0.05 & 6.32 \\
Newlyn & 0.42 & 0.46 & 0.99 & -0.31 & 5.17 \\
Newport & 0.56 & 0.67 & 0.98 & 0.31 & 20.11 \\
StMarys & 0.40 & 0.43 & 0.99 & -0.34 & 6.90 \\
Tobermory & 0.32 & 0.35 & 0.99 & -0.21 & 33.33 \\
Ullapool & 0.29 & 0.33 & 0.99 & -0.19 & 31.61 \\
Whitby & 0.27 & 0.32 & 0.99 & -0.03 & 32.18 \\
\hline Mean total & 0.30 & 0.35 & 0.99 & -0.08 & 19.78 \\
\hline
\end{tabular}

Code and data availability. The nature of the 4-D data generated in running the various experiments requires a large tape storage facility to maintain the model data. These data amount to several tens of terabytes archived on the Met Office MASS system. These data can be made available to interested researchers by contacting the author and will require signing of licence agreements in order to access the data. Each simulation namelist and input data are also archived under configuration management, hosted by the Met Office, and can be made available to others upon contacting the authors. The model was validated against TG from BODC, accessible at https://www.bodc.ac.uk/data/hosted_data_systems/sea_level/uk_ tide_gauge_network/ (National Oceanography Centre \& Environment Agency, 2020).
The processed model outputs used in this study have been made available on Zenodo (https://doi.org/10.5281/zenodo.4701064, Rulent, 2021).

Author contributions. JR, LMB, and JAMG designed the research. JR led the study, performed the research and the data analysis, and produced the figures. LB and JAMG helped with the data analysis/interpretation and fundamentally helped in developing the manuscript and figures. HL provided the numerical model data and helped understand all aspects related to the numerical model. IDH helped with selecting the case study and understanding aspects related to surges and their impact during extreme events. HL and IDH also helped revise and improve the work and manuscript.

Competing interests. The contact author has declared that neither they nor their co-authors have any competing interests.

Disclaimer. Publisher's note: Copernicus Publications remains neutral with regard to jurisdictional claims in published maps and institutional affiliations.

Acknowledgements. This work used Monsoon2, a collaborative High-Performance Computing facility funded by the Met Office and the Natural Environment Research Council (NERC). This research has been carried out under national capability funding as part of a directed effort on UK Environmental Prediction, in collaboration between the Centre for Ecology \& Hydrology (CEH), the Met Office, National Oceanography Centre (NOC), and Plymouth Marine Laboratory (PML).

Financial support. This research has been supported by the UK Research and Innovation (grant no. CLASS-WP5).

Review statement. This paper was edited by Joaquim G. Pinto and reviewed by Patrick Ludwig and two anonymous referees.

\section{References}

Ardhuin, F., Roland, A., Dumas, F., Bennis, A. C., Sentchev, A., Forget, P., Wolf, J., Girard, F., Osuna, P., and Benoit, M.: Numerical wave modeling in conditions with strong currents: Dissipation,refraction, and relative wind, J. Phys. Oceanogr., 42, 21012120, https://doi.org/10.1175/JPO-D-11-0220.1, 2012.

Arns, A., Wahl, T., Wolff, C., Vafeidis, A. T., Haigh, I. D., Woodworth, P., Niehüser, S., and Jensen, J.: Non-linear interaction modulates global extreme sea levels, coastal flood exposure, and impacts, Nat. Commun., 11, 1-9, https://doi.org/10.1038/s41467-020-15752-5, 2020. 
Bertin, X., Li, K., Roland, A., and Bidlot, J. R.: The contribution of short-waves in storm surges: Two case studies in the Bay of Biscay, Cont. Shelf Res., 96, 1-15, https://doi.org/10.1016/j.csr.2015.01.005, 2015.

Chartteron, J., Clarke, C., Daly, E., Dawks, S., Elding, C., Fenn, T., Hick, E., Miller, J., Morris, J., Ogunyoye, F., and Salado, R.: The costs and impacts of the winter 2013 to 2014 floods, available at: https://www.gov.uk/government/publications/ the-costs-and-impacts-of-the-winter-2013-to-2014-floods (last access: 25 February 2021), 2016.

Coles, S.: An introduction to statistical modeling of extreme values, in: Springer series in statistic, Springer-Verlag, London, UK, 2001.

Committee on Climate Change: Managing the land in a changing climate (Chapter 4), Progress report 2013, 70-91, available at: http://www.theccc.org.uk/wp-content/uploads/2013/07/ ASC-2013-Chap4_singles_2.pdf (last access: 28 May 2020), 2013.

Cox, R., Jahn, K. L., Watkins, O. G., and Cox, P.: Extraordinary boulder transport by storm waves (west of Ireland, winter 2013-2014), and criteria for analysing coastal boulder deposits, Earth-Sci. Rev., 177, 623-636, https://doi.org/10.1016/j.earscirev.2017.12.014, 2018.

Cullen, M. J.: unified-forecast climate-model, Meteorological office, 122, 88-94, 1993.

Dangendorf, S., Arns, A., Pinto, J. G., Ludwig, P., and Jensen, J.: The exceptional influence of storm "Xaver" on design water levels in the German Bight, Environ. Res. Lett., 11, 054001, https://doi.org/10.1088/1748-9326/11/5/054001, 2016.

De Dominicis, M., Wolf, J., Jevrejeva, S., Zheng, P., and Hu, Z.: Future Interactions Between Sea Level Rise, Tides, and Storm Surges in the World's Largest Urban Area, Geophys. Res. Lett., 47, e2020GL087002, https://doi.org/10.1029/2020GL087002, 2020.

Del Río, L., Plomaritis, T. A., Benavente, J., Valladares, M., and Ribera, P.: Establishing storm thresholds for the Spanish Gulf of Cádiz coast, Geomorphology, 143-144, 13-23, https://doi.org/10.1016/j.geomorph.2011.04.048, 2012.

Dhoop, T. and Mason, T.: Spatial characteristics and duration of extreme wave events around the English coastline, Journal of Marine Science and Engineering, 6, 14, https://doi.org/10.3390/jmse6010014, 2018.

Flather, R. A.: Existing operational oceanography, Coastal Eng., 41, 13-40, https://doi.org/10.1016/S0378-3839(00)00025-9, 2000.

Graham, J. A., O’Dea, E., Holt, J., Polton, J., Hewitt, H. T., Furner, R., Guihou, K., Brereton, A., Arnold, A., Wakelin, S., Castillo Sanchez, J. M., and Mayorga Adame, C. G.: AMM15: a new high-resolution NEMO configuration for operational simulation of the European north-west shelf, Geosci. Model Dev., 11, 681696, https://doi.org/10.5194/gmd-11-681-2018, 2018.

Haigh, I. D., Wadey, M. P., Gallop, S. L., Loehr, H., Nicholls, R. J., Horsburgh, K., Brown, J. M., and Bradshaw, E.: A user-friendly database of coastal flooding in the United Kingdom from 19152014, Sci. Data, 2, 1-13, https://doi.org/10.1038/sdata.2015.21, 2015.

Haigh, I. D., Wadey, M. P., Wahl, T., Ozsoy, O., Nicholls, R. J., Brown, J. M., Horsburgh, K., and Gouldby, B.: Spatial and temporal analysis of extreme sea level and storm surge events around the coastline of the UK, Sci. Data, 3, 1-14, https://doi.org/10.1038/sdata.2016.107, 2016.

Haigh, I. D., Ozsoy, O., Wadey, M. P., Nicholls, R. J., Gallop, S. L., Wahl, T., and Brown, J. M.: An improved database of coastal flooding in the United Kingdom from 1915 to 2016, Sci. Data, 4, 1-10, https://doi.org/10.1038/sdata.2017.100, 2017.

Home Office: National Risk Register Of Civil Emergencies 2017 edition, Tech. rep., available at: http://www.official-documents. gov.uk (last access: 15 October 2019), 2017.

Horsburgh, K., Rennie, A., and Palmer, M.: Impacts of climate change on sea-level rise relevant to the coastal and marine environment around the UK, Marine Climate Change Impacts Partnership, Scotland's Marine Assessment 2020 - Scottish government, Scotland, 116-131, 2020.

Horsburgh, K. J. and Wilson, C.: Tide-surge interaction and its role in the distribution of surge residuals in the North Sea, J. Geophys. Res.-Oceans, 112, 1-13, https://doi.org/10.1029/2006JC004033, 2007.

Idier, D., Bertin, X., Thompson, P., and Pickering, M. D.: Interactions Between Mean Sea Level, Tide, Surge, Waves and Flooding: Mechanisms and Contributions to Sea Level Variations at the Coast, Surv. Geophys., 40, 1603-1630, https://doi.org/10.1007/s10712-019-09549-5, 2019.

Janjić, J., Gallagher, S., and Dias, F.: Case study of the winter 2013/2014 extreme wave events off the west coast of Ireland, Adv. Sci. Res., 15, 145-157, https://doi.org/10.5194/asr-15-1452018, 2018.

Kandrot, S., Farrell, E., and Devoy, R.: The morphological response of foredunes at a breached barrier system to winter 2013/2014 storms on the southwest coast of Ireland, Earth Surf. Proc. Land., 41, 2123-2136, https://doi.org/10.1002/esp.4003, 2016.

Khanal, S., Ridder, N., de Vries, H., Terink, W., and van den Hurk, B.: Storm Surge and Extreme River Discharge: A Compound Event Analysis Using Ensemble Impact Modeling, Front. Earth Sci., 7, 1-15, https://doi.org/10.3389/feart.2019.00224, 2019.

Kirezci, E., Young, I. R., Ranasinghe, R., Muis, S., Nicholls, R. J., Lincke, D., and Hinkel, J.: Projections of globalscale extreme sea levels and resulting episodic coastal flooding over the 21st Century, Sci. Rep.-UK, 10, 1-12, https://doi.org/10.1038/s41598-020-67736-6, 2020.

Lawless, M., Hird, M., Rodger, D., Gouldby, B., Tozer, N., Pullen, T., Saulter, A., and Horsburgh, K.: Coastal flood forecasting - a Good practice framework, p. 72, available at: https://assets.publishing.service.gov.uk/government/uploads/ system/uploads/attachment_data/file/570156/Coastal_flood_ forecasting__a_good_practice_framework_-_report.pdf (last access: 16 April 2020), 2016.

Lewis, H. W., Castillo Sanchez, J. M., Arnold, A., Fallmann, J., Saulter, A., Graham, J., Bush, M., Siddorn, J., Palmer, T., Lock, A., Edwards, J., Bricheno, L., Martínez-de la Torre, A., and Clark, J.: The UKC3 regional coupled environmental prediction system, Geosci. Model Dev., 12, 2357-2400, https://doi.org/10.5194/gmd-12-2357-2019, 2019a.

Lewis, H. W., Castillo Sanchez, J. M., Graham, J., Saulter, A., Bornemann, J., Arnold, A., Fallmann, J., Harris, C., Pearson, D., Ramsdale, S., Martínez-de la Torre, A., Bricheno, L., Blyth, E., Bell, V. A., Davies, H., Marthews, T. R., O’Neill, C., Rumbold, H., O'Dea, E., Brereton, A., Guihou, K., Hines, A., Butenschon, M., Dadson, S. J., Palmer, T., Holt, J., Reynard, N., Best, M., 
Edwards, J., and Siddorn, J.: The UKC2 regional coupled environmental prediction system, Geosci. Model Dev., 11, 1-42, https://doi.org/10.5194/gmd-11-1-2018, 2018.

Lewis, H. W., Castillo Sanchez, J. M., Siddorn, J., King, R. R., Tonani, M., Saulter, A., Sykes, P., Pequignet, A.-C., Weedon, G. P., Palmer, T., Staneva, J., and Bricheno, L.: Can wave coupling improve operational regional ocean forecasts for the north-west European Shelf?, Ocean Sci., 15, 669-690, https://doi.org/10.5194/os-15-669-2019, 2019 b.

Lewis, M. J., Palmer, T., Hashemi, R., Robins, P., Saulter, A., Brown, J., Lewis, H., and Neill, S.: Wave-tide interaction modulates nearshore wave height, Ocean Dynam., 69, 367-384, https://doi.org/10.1007/s10236-018-01245-z, 2019c.

Li, J. G.: Global transport on a spherical multiplecell grid, Mon. Weather Rev., 139, 1536-1555, https://doi.org/10.1175/2010MWR3196.1, 2011.

Lyddon, C. E., Brown, J. M., Leonardi, N., Saulter, A., and Plater, A. J.: Quantification of the Uncertainty in Coastal Storm Hazard Predictions Due to Wave-Current Interaction and Wind Forcing, Geophys. Res. Lett., 46, 14576-14585, https://doi.org/10.1029/2019GL086123, 2019.

Madec, G. and the NEMO Team: NEMO Ocean Engine, Note du Póle de modélisation, 1-332, 2008.

Marcos, M., Rohmer, J., Vousdoukas, M. I., Mentaschi, L., Le Cozannet, G., and Amores, A.: Increased Extreme Coastal Water Levels Due to the Combined Action of Storm Surges and Wind Waves, Geophys. Res. Lett., 46, 4356-4364, https://doi.org/10.1029/2019GL082599, 2019.

Met Éireann: Exceptional Weather Events - Winter 2013/2014, Irish Meteorological Service, available at: https://www.met. ie/cms/assets/uploads/2017/08/WinterStorms13_14.pdf (last access: 7 February 2021), 2014.

Moftakhari, H., Schubert, J. E., AghaKouchak, A., Matthew, R. A., and Sanders, B. F.: Linking statistical and hydrodynamic modeling for compound flood hazard assessment in tidal channels and estuaries, Adv. Water Resour., 128, 28-38, https://doi.org/10.1016/j.advwatres.2019.04.009, 2019.

National Oceanography Centre \& Environment Agency: UK Tide Gauge Network, BODC [data set], available at: https://www.bodc.ac.uk/data/hosted_data_systems/sea_level/ uk_tide_gauge_network/, last access: 11 June 2020.

Nidzieko, N. J.: Tidal asymmetry in estuaries with mixed semidiurnal/diurnal tides, J. Geophys. Res.-Oceans, 115, 1-13, https://doi.org/10.1029/2009JC005864, 2010.

Priestley, M. D., Pinto, J. G., Dacre, H. F., and Shaffrey, L. C.: The role of cyclone clustering during the stormy winter of 2013/2014, Weather, 72, 187-192, https://doi.org/10.1002/wea.3025, 2017.

RMS: 2013-2014 WINTER STORMS IN EUROPE: An Insurance and Catastrophe Modeling Perspective, p. 27, Risk Management Solutions, Inc., available at: https://forms2.rms.com/rs/729-DJX-565/images/ws_2013_ 2014_europe_winter_storms.pdf (last access: 24 June 2021), 2014.

Rossiter, J. R.: Interaction Between Tide and Surge in the Thames, Geophys. J. Roy. Astr. S., 6, 29-53, https://doi.org/10.1111/j.1365-246X.1961.tb02960.x, 1961.

Rulent, J.: Dataset Manuscript: Coastal High Water Level Distribution During Storms, Zenodo [code], https://doi.org/10.5281/zenodo.4701064, 2021.
Sánchez-Arcilla, A., García-León, M., Gracia, V., Devoy, R., Stanica, A., and Gault, J.: Managing coastal environments under climate change: Pathways to adaptation, Sci. Total Environ., 572, 1336-1352, https://doi.org/10.1016/j.scitotenv.2016.01.124, 2016.

Sibley, A., Cox, D., and Titley, H.: Coastal flooding in england and wales from atlantic and north sea storms during the 2013/2014 winter, Weather, 70, 62-70, https://doi.org/10.1002/wea.2471, 2015 .

Siddorn, J. R., Good, S. A., Harris, C. M., Lewis, H. W., Maksymczuk, J., Martin, M. J., and Saulter, A.: Research priorities in support of ocean monitoring and forecasting at the Met Office, Ocean Sci., 12, 217-231, https://doi.org/10.5194/os-12217-2016, 2016.

Spencer, T., Brooks, S. M., Evans, B. R., Tempest, J. A., and Möller, I.: Southern North Sea storm surge event of 5 December 2013: Water levels, waves and coastal impacts, Earth-Sci. Rev., 146, 120-145, https://doi.org/10.1016/j.earscirev.2015.04.002, 2015.

Stevens, A. J., Clarke, D., and Nicholls, R. J.: Trends in reported flooding in the UK: 1884-2013, Hydrolog. Sci. J., 61, 50-63, https://doi.org/10.1080/02626667.2014.950581, 2016.

Stocker, T. F., Qin, D., Plattner, G. K., Tignor, M. M., Allen, S. K., Boschung, J., Nauels, A., Xia, Y., Bex, V., and Midgley, P. M.: Climate change 2013 the physical science basis: Working Group I contribution to the fifth assessment report of the intergovernmental panel on climate change, Climate Change 2013 the Physical Science Basis: Working Group I Contribution to the Fifth Assessment Report of the Intergovernmental Panel on Climate Change, 9781107057, 1-1535, https://doi.org/10.1017/CBO9781107415324, 2013.

Thorne, C.: Geographies of UK flooding in 2013/4, Geogr. J., 180, 297-309, https://doi.org/10.1111/geoj.12122, 2014.

Tolman, H. L. and Iii, W.: User manual and system documentation of WAVEWATCH III R version 4.18, NOAA/NCEP/EMC, Tech. note number 316, U. S. Department of Commerce National Oceanic and Atmospheric Administration, National Weather Service National Centers for Environmental Prediction, College Park, MD, USA, 2014.

Valcke, S., Craig, T., and Coquart, L.: OASIS3-MCT User Guide, Tech. Rep. May, CERFACS/CNRS, Toulouse, France, 2015.

Valiente, N. G., Saulter, A., Edwards, J. M., Lewis, H. W., Sanchez, J. M., Bruciaferri, D., Bunney, C., and Siddorn, J.: The impact of wave model source terms and coupling strategies to rapidly developing waves across the north-west european shelf during extreme events, Journal of Marine Science and Engineering, 9, 403, https://doi.org/10.3390/jmse9040403, 2021.

Vousdoukas, M. I., Mentaschi, L., Voukouvalas, E., Verlaan, M., Jevrejeva, S., Jackson, L. P., and Feyen, L.: Global probabilistic projections of extreme sea levels show intensification of coastal flood hazard, Nat. Commun., 9, 1-12, https://doi.org/10.1038/s41467-018-04692-w, 2018.

Wadey, M. P., Haigh, I. D., and Brown, J. M.: A century of sea level data and the UK's 2013/14 storm surges: an assessment of extremes and clustering using the Newlyn tide gauge record, Ocean Sci., 10, 1031-1045, https://doi.org/10.5194/os-10-10312014, 2014. 
Williams, J. A. and Horsburgh, K. J.: Evaluation and comparison of the operational Bristol Channel Model storm surge suite, National Oceanography Centre Research \& Consultancy Report No. 38, https://doi.org/10.1017/CBO9781107415324.004, 2013.
Wolf, J.: Coastal flooding: Impacts of coupled wavesurge-tide models, Natural Hazards, 49, 241-260, https://doi.org/10.1007/s11069-008-9316-5, 2009. 